\title{
A Witness in Red Stockings
}

“T here's no pain on earth that doesn't crave a benevolent witness," says eleven-year-old Sarah Grimke in Sue Monk Kidd's (2014) The Invention of Wings after she is humiliated at the hands of her mother. The benevolent witness is a tenyear-old slave named Handful. Although Monk's novel is not intended for young readers, she has crafted a beautiful, singular phrase that transcends genre.

The world of young adult literature is filled with benevolent witnesses. Armed with an unvarnished honesty, they describe the indescribable, take us to places we would otherwise never reach, lift the lid on bitter truths that cannot and should no longer be contained. They inject their insights with humor, a directness that can make us squirm or laugh or stop us in our tracks.

Sometimes benevolent witnesses step forward decades after a scarring experience that has seared their soul and left a stain that no amount of revisionism or skepticism can scrub away. It can take years before the world is ready to open its ears to cries that were initially muted, stunned into silence. Bodies of literature that are, in essence, testimonies-as-art aren't simply hatched; those who live to chronicle the unspeakable must first believe they have the legitimacy to share their stories, and that journey can take a long time. A benevolent witness has to be ready to speak; the world has to be ready to listen.

\section{Voices Silenced}

Phrases like "the Holocaust" and "slavery" have become shorthand for moments when our collective humanity collapsed, and books for young readers slowly emerged from the long shadows they cast to contribute to the painstaking process of repairing our fractured, fragile world. Now there are shelves of books that sag from the weight of the damage we have wrought in the name of warped ideologies. In time, a phrase like "residential schools" may find its way into our consciousness, into conversations, and onto bookshelves, thanks to authors like Margaret Pokiak-Fenton (and co-author Christy Jordan-Fenton), who had younger readers in mind when she revisited the trauma she endured as a young girl.

"My name is Olemaun Pokiak-that's Oo-leemawn," says Pokiak-Fenton (2010) in Fatty Legs, a memoir of her years spent in a residential school in the Canadian Arctic, an experience of witnessing she shares through her daughter-in-law, author Christy Jordan-Fenton. "I am going to let you in on a secret that I have kept for more than 60 years" (p. 1). Over the course of a hundred or so pages, that secret is unraveled in language that points a damning finger at systemic racism as it paints a compelling portrait of a young girl determined to stand her ground after she has been uprooted.

The Truth and Reconciliation Commission of Canada was officially established in June 2008. For the next six years, the commission travelled across the country to hear some 6000 Aboriginal people describe in their own words what it was like to be taken from their families and shipped to distant schools whose primary aim was to strip these children of their identity-schools where they learned ABCs of a whole other order: A is for abuse; $\mathrm{B}$ is for beating; $\mathrm{C}$ is for the cultures that were crushed in these governmentrun classrooms where children were forbidden to 
speak their native languages. Approximately 150,000 children attended these schools from the time they first opened in the 1870s until the last one was shuttered in 1996.

These so-called schools weren't designed Traditionally, history to enrich young minds so is written, sealed, and preserved by the victors. A book like Fatty Legs upends that tradition and gives voice to victims whose stories would have otherwise gone unnoticed and unheard. under the care of the schools' teachers. much as they pounded young souls into believing their culture, their very sense of being, was inferior to everything and anything the white teachers had to offer. The thousands of residential survivors who shared their harrowing stories with the Commission were the lucky ones, if you will, compared to the 4,000 children who were reported to have died, some in unmarked graves, while

\section{Voices Heard}

When pain and sorrow are contained like a river that is dammed, it takes benevolent witnesses like PokiakFenton to wield the small pick axes that chip away at those stone walls and let the stories burst through. Traditionally, history is written, sealed, and preserved by the victors. A book like Fatty Legs upends that tradition and gives voice to victims whose stories would have otherwise gone unnoticed and unheard.

In hindsight, Pokiak-Fenton unearths a dichotomy she could not have discovered as a young girl: the clenched fist of an oppressor can also open doors. In this case, the door was a portal into literature. PokiakFenton passionately wants to learn how to read, all the more so after she is told about the magical tale of Alice in Wonderland. Like any other child the world over, she is desperate to go to school, keen to spend her days with her nose in a book. She describes seeing the white teachers who worked at the residential schools:

I was mesmerized on each trip by the spectacle of the strange dark-cloaked nuns, whose tongues flickered with FrenchCanadian accents and the pale-skinned priests who had travelled across a different ocean from a far-off land called Belgium. They held the key to the greatest of the outsiders' mysteries-reading. (p. 4)

Year after year, she asks her father if she can finally go to school in Aklavik, a five-day journey from home on an island in the Arctic Ocean. Her father, who Pokiak-Fenton describes as a smart man who loved to read, doesn't mince words when he tries to dissuade his daughter: "The outsiders do not teach you how to hunt," he warns her. "They feed you cabbage and porridge .... They teach you their songs and dances instead of your own. And they tell you that the spirit inside you is bad and needs their forgiveness" (p. 11).

What Pokiak-Fenton does so well in Fatty Legs is stay true to who she was as a young child. She preserves the naiveté that makes children children, the assumption that goodness is affirmed, and the only ones who pay a price are those who misbehave. She writes that she was determined to stay out of trouble, unaware that her teachers would play by a different rule book altogether. It's that childlike innocence that anchors a line like, "They would see that my spirit was good” (p. 11).

Faced with a stubborn child, Pokiak-Fenton's father uses a stone as a beautiful but forceful metaphor for what she can expect. He picks up a rock and, in Pokiak-Fenton's artful writing, tells her that the stone "was once jagged and full of sharp, jutting points, but the water of the ocean slapped and slapped at it, carrying away its angles and edges. Now it is nothing but a small pebble. That is what the outsiders will do to you at school" (p. 13). Like all strong-willed children, Poliak-Fenton allows nothing to stand between her and what she wants. Not even the warning that the school's nuns will cut her long, beautiful hair or that she will be forbidden from talking to her cousin, as boys and girls were separated. The warnings leave her unscathed, and by 1944, Pokiak-Fenton's father relents and allows her to go to school.

Most of us can recall our first day at school as a mixture of nervous anticipation mixed with a dollop of excitement. The school year lay before us like a blank page. At residential schools, a child's fate was predetermined. The nuns were there to save children like Pokiak-Fenton from the clutches of a so-called backwards culture. "An outsider with a hooked nose like a beak came for me," she recalls, upon meet- 
ing the nun she would call the Raven, "her scraping footsteps echoing through the long, otherwise silent halls. 'I am glad you have come to your senses,' she told my father in Inuvialuktun. 'You certainly can't teach her the things she needs to know.' She wrapped a dark-cloaked arm around my shoulder and ushered me away, without giving me a chance to say goodbye" (p. 28).

History has shown that one of the most effective ways to diminish a people is not only through physical assault—a slave master's whip, a Nazi's boot. As Pokiak-Fenton's father pointed out to her, you can wear people down by humiliating them as surely as water wears down stone. When she was warned that the nuns would cut her hair, she brushed it off. But then the moment came when it happened, when a nun showed up bearing shears. As a benevolent witness, Pokiak-Fenton uses language that provokes and evokes:

"I can fix my own hair," I protested in Inuvialuktun, but she held it tight and, with the same motion a bird makes to pull a piece of flesh from a fish, clamped the jaws of the shears down on my braid and severed it. I was horrified. I wasn't a baby. My other braid fell to the floor to meet the first, and I joined the others in their weeping. (p. 31)

Pokiak-Fenton also learns firsthand an enduring but pointed truth about human nature: when a group of people is mistreated, humiliated, devalued, then there are those within that group who will do the same amongst their own. In other words, douse people with invective, and they will wring that abuse over the head of another. The abused becomes the abuser. In the case of Fatty Legs, the abused-turned-abuser is a Gwich'in girl named Katherine who compounds Margaret's misery. The Gwich'in are Athabaskanspeaking Aboriginal people who live mostly above the Artic Circle. "The Gwich'in always thought they were better than us," Margaret recalls (p. 36).

One incident stands out where Katherine's laughter is as painful as any physical bruise:

I placed some paste from the tube on the end of my toothbrush, and stuck it in my mouth. . . . It was worse than a fly's breakfast. I couldn't help but gag and spit it out. The raven-like nun called out "Katherine," and the Gwich'in girl who had smiled when my hair was cut tore the tube from my hand and took it to her. The nun cackled and held the tube up for other girls to see. The older ones laughed loudly, especially the Gwich'in girl called Katherine. . . .
A tall slender nun appeared in the doorway. She was pale and seemed to float across the bathroom floor. She turned to the Raven, seeking an explanation for the commotion.

I could hardly take my eyes off her.

The Raven made a gesture from her cheekbone to her jaw, like a man shaving whiskers. The new girls now laughed, too.

My mother had bought the tube for me. They were not just laughing at me. They were laughing at her. I wanted to tell the nun that it was not funny. My mother could not read. How was she to know that she was buying shaving cream and not toothpaste? (p. 37)

The humiliation of arrow-sharp laughter, of having beloved braids shorn, was just one part of the arsenal teachers used to break down the very children whose lives they were meant to fortify. But the truth is, the young First Nations children weren't seen as bright minds that a teacher's touch could help mold. They were, instead, little more than commodities. "It wasn't just the chores," Pokiak-Fenton writes, speaking of how students labored in ways that can only be described as punishment. The nuns "were paid by the government per student and plucking us from our homes and keeping us in their nests was a moneymaking business” (p. 55). The church-run schools were, in their own way, more about being entrepreneurs who traded in human lives than educators committed to shaping them.

When Pokiak-Fenton is finally given the opportunity to set the record straight, she speaks with the unfiltered honesty that is the hallmark of children's voices. It is unadorned, shorn of ornate language as it reveals a quiet despair beneath. "Dear Mother and Father," begins a letter she has been instructed to write to her parents, as dictated by the Raven. Instead of parroting her teacher's lies-in a different context, it would be labeled propaganda-Pokiak-Fenton braves the consequences of speaking truth to power. "I hate this school," she bluntly states. "You were right. The food is awful and the nuns are very mean. They won't even let me wear the stockings you bought for me. As you can see, I have already learned to read and write. Please, come to get me as soon as you can. I am ready to go home" (p. 61).

Pokiak-Fenton's plainspoken, piercing words never make it to the air. The letter is torn in half. The nuns decide the best way to prevent incorrigible chil- 
dren from writing a subversive letter is to have them read scripted, glowing dispatches over the airwaves. As Pokiak-Fenton steps into the radio station where her message is expected to be broadcast far and wide, she is handed a pre-written note: "Hello, Mom! Hello, Dad! it read. Merry Christmas! I miss you, but the nuns here treat us like family and school is very fun" (p. 63)

We have entered a wonderland of a tyrant's making. In the opening pages of Fatty Legs, Pokiak-Fenton writes that she tried imagining what it was like being Alice and notes that "she was brave to go into that long, dark tunnel, all for curiosity” (p. 5). She reveals her own bravery after she's been handed the scripted letter she's expected to read over the air: "I stood in front of the microphone. Mother, Father, get me out of here, please. Take me home! I'm freezing and my teacher is wicked and mean, I thought, but I said nothing. Not one word. I never stopped talking at home; my silence would surely tell them that something was wrong" (p. 64).

Of all the ways children communicate their true feelings, silence is one of the most profound examples of self-expression, and it behooves adults to pay attention to what children don't say as much as we latch on to the words they do share.

The nuns don't take kindly to Pokiak-Fenton's silent protest. For every benevolent witness, there is a culprit. Come the day when all the girls are given new black stockings, she is handed a pair that is red. "I looked like a plump-legged circus clown," she writes (p. 67). Hence the corrosive nickname Fatty Legs. And if Pokiak-Fenton has endured a trial by fire, it is the flames beneath the vat in a laundry room where she finds salvation. A system bent on breaking children found its match in young Margaret. "Be careful what birds you choose to pluck from their nests," she writes. "A wren can be just as clever as a raven" (p. 74). She tosses her red stockings into the flames, and when a kind-hearted nun named Sister MacQuillan takes her under her wing, she savors a quiet but important triumph.

It is Sister MacQuillan who gives Pokiak-Fenton a parting gift when she receives word that her parents want her to come home. "You will be very missed, Margaret," she says as she hands her a copy of Alice's
Adventures in Wonderland. And then she continues: "You will be very missed, Olemaun" (p. 77). Hearing her real name brings tears to Olemaun's eyes.

Her long-awaited reunion does not unfold as anticipated. "Not my girl," her mother says after the two-year absence. "Not my girl” (p. 79). Her daughter, of course, had changed from the eight-year-old she once knew to the ten-year-old who now stood before her, changed in ways that could be seen and in ways that Pokiak-Fenton would keep to herself for decades.

After two years in residential school, Pokiak-Fenton had to relearn who she once was. Before bed her first night back home, she read from Alice in Wonderland. "My curiosity had led me far away," she says in the closing paragraph. "And now here I was, after two years, satisfied that I now knew what happened to girls who went down rabbit holes" (p. 82).

That is why we need books like Fatty Legs, told through the lens of a young benevolent witness who can slip down rabbit holes and unearth painful truths that we owe it to ourselves to confront, truths that would otherwise forever remain buried and unmarked.

Emil Sher writes prose and plays for the young and the once-were-young. His debut novel for young adult readers, Young Man with Camera, was a 2015 VOYA Perfect Ten, a 2015 Chapter Book Favorite of the International Literacy Association, and a 2016 White Raven book. Other works of children's literature include two board books, A Button Story and A Pebble Story, and two picturebooks, Mittens to Share and Away, a story told through sticky notes. Emil abridged Mona Golabek's The Children of Willesden Lane for young readers. His stage adaptation of Hana's Suitcase, the beloved Holocaust book by Karen Levine, has been performed across the US and Canada. Other stage plays include The Book of Ashes, inspired by the true story of an Iraqi librarian who saved over 30,000 books in the midst of war, and the adaptation of Marie Edwards's Edward the 'Crazy Man,' a chronicle of the bond between a young boy and a homeless man living with schizophrenia.

\section{References}

Jordan-Fenton, C., \& Pokiak-Fenton, M. (2010). Fatty legs. Toronto, Canada: Annick Press.

Kidd, S. M. (2014). The invention of wings. New York, NY: Viking. 